INTERNATIONAL JOURNAL OF RESEARCHES IN BIOSCIENCES, AGRICULTURE \& TECHNOLOGY (C) VISHWASHANTI MULTIPURPOSE SOCIETY (Global Peace Multipurpose Society) R. No. MH-659/13(N) www.vmsindia.org

\title{
ICHTHYOFAUNAL DIVERSITY AND SCENARIO ON SOCIO-ECONOMIC STATUS OF FISHERMEN AROUND THE UMA RIVER, DISTRICT WASHIM (M.S.), INDIA
}

Avinashe A. M. and Mukwane R. C.

S.S.S.K.R. Innani College, Karanja (Lad), Washim (M.S) India Email: ravindramukwane@gmail.com

\begin{abstract}
Study of ichthyofaunal diversity and also the socio-economical status of fishermen community. Survey of Uma River was carried out for a period of one year from July 2015 to June 2016 . We have recorded 28 species belonging to 7 orders, 9 families and 23 genera. Cypriniformes order dominated with 16 species followed by order siluriformes, perciformes and synbranchiformes each with 3 species and atheriniformes, osteoglossiformes and anguliformes each with 1 species where as members of order siluriformes, atheriniformes and anguiliformes were on declining mode. Beside this study was taken to investigate the socio-economic status of the fishermen around the Uma River. Forty four fishermen were randomly selected from these areas who were solely involved in fishing in Uma River. Personal interview, cross check interview with extension agents, older persons were to collect the information about socioeconomic status. In view of lack of information of fish diversity and socio-economic status of fishermen around the Uma River, present survey was undertaken.
\end{abstract}

Keywords: Uma River, Siluriformes, Cypriniformes, Fishermen, Socio-economic status

\section{Introduction:}

Uma River is one of the river in Washim district showing a rich fish diversity. According to Saunders D. L. et al, (2002) and $\mathrm{Li} \mathrm{Li}$ et al, (2010) rivers are one of the extensively studied ecosystems world over. It has been illustrated that these ecosystems are the most threatened ecosystem worldwide. Likewise, as per the Kamp et al, (2007) Rivers perform important ecological functions such as development of ecosystem enhance productivity, natural flood control and species diversity conservation. Alan D.J. (2004), a healthy and intact riparian area not only protects stream structure but also stabilizes stream banks and riverine ecosystem.

Kar et. al, (2003) were reported that around the world approximately 22,000 species of fishes of which nearly 2,420 are found in India, from these 930 found in fresh water and 1,570 are in marine habitat. Maharashtra is one of the important states for fish production and natural water resources. There is great scope for developing fisheries in this state. Order cypriniformes includes the fish species are one of the most important groups of vertebrates for man. The nutritive as well as medicinal value of fish has been recognized from ancient time to recent era. There is a wide scope for the further development in the fisheries sector however; very less information is available about ichthyofauna present in the lotic and lentic habitats of Washim district. Therefore present attempt has been made to document the fish fauna available in Uma river and aim to scientific utilization for agricultural irrigation and fisheries activities, for sustained exploitation and simultaneous conservation of fisheries resources, basic scientific information on biodiversity. There is urgent need to carry out data about socio-economic status of fishermen population and formulation of schemes to help them to improve the overall status.

\section{Materials and Methods:}

Uma river is originated from Tapovan of Karanja Tehsil, Dist. Washim and merges into the Purna River at Durgawada of Murtijapur Tehsil Dist. Akola. Uma River is located at the latitude $29.73^{\circ} \mathrm{N}$ and longitude $77.51^{0} \mathrm{E}$. This river flows from Tapovan to Durgawada and the length is about $67 \mathrm{Km}$. its drainage basin is shared by near about 27 villages having 02 dams, which are used for irrigation, drinking, fishing purposes etc.

To investigate Ichthyofaunal diversity of the Uma river, freshly dead fishes were taken from fish markets for photographs and study purpose. The identification of the fish species was done on the basis of the 
color pattern, specific spots or marks on outer body surface, body shape, structure of fins, mouth shapes etc. which are given in taxonomic key of Talwar and Jhingran (1991), Jayaram and Sanyal (2003). A study on ichthyofaunal diversity of Uma River has been made find out during July 2015 to June 2016.

In this piece of study was also composed of a livelihood systems assessment of fishermen community depends on Uma River. The initial data was collected through the questionnaire, survey, group discussion and interview with men which is related various activities of fishing. Monthly field survey was carried out to collect the necessary information through random selection method. A total of forty four fishermen and their households were surveyed in seven villages as Tapovan, Poha, Kajleshwar, Kherda, Muramba, Mana and Durgwada. The collected information was cross-checked for ensuring the accuracy finds from the respondents.

\section{Result and Discussion:}

Result of the present study revealed the occurrence of 28 fish species belonging to 7 orders, 9 families and 23 genera were recorded from Uma River of Dist. Washim. Many workers are studied Taxonomy, biodiversity and distribution of fishes found in freshwater bodies of various parts of India. Similar studies were carried out by Shinde S. E. et. al., (2009) that the freshwater fish biodiversity during period January 2008 to December 2008 to census and commercially important fishes in the Pravara River Dist. Ahmednagar. The result of present investigation showed that there were occurrence of 41 fish species belonging to 7 orders, 14 families and 26 genera. Thirumala S. et al, (2011) were reported the freshwater fish fauna of Bhadra reservoir during a period from June 2004 to May 2005. They were recorded 33 fish species belonging to 10 families. Kharat S.S. et. al.,(2012) were taken a survey of freshwater fish fauna of the Krishna river at Wai, and Dhom reservoir of stream of Wai. There were 51 fish species belonging to 14 families and 33 genera were recorded; 13 endemic to the Western Ghats and 2 from Krishna river system. Similar results were found by Jayabhaye et al, (2013) ichthyofaunal diversity of Pimpaldari tank in Hingoli district Maharashtra was found occurrence of 21 fish species belonging to 5 orders, 6 families and 13 genera. Nagma et al, (2013) were undertaken ichthyofaunal studies during the period February 2012 to January 2013 in the rivers, reservoirs and ponds of district Bijnor U.P. The result of present investigation revealed that occurrence of 36 fish species belonging to 23 different genera, in 11 families, 6 orders were recorded.

In present study following are the fish species found in Uma river.

Chart No. 1 - Ichthyofaunal Diversity of Uma River Dist. Washim (M.S.)

\begin{tabular}{|l|l|l|l|l|}
\hline Sr. No. & Order & Family & Species & Local name \\
\hline 1 & Cypriniformes & Cyprinidae & Catla catla & Catla \\
\hline 2 & & & Labeo rohita & Rohu \\
\hline 3 & & & Labeo bata & Tembti \\
\hline 4 & & & Labeo boga & Chankora \\
\hline 5 & & & Labeo pangsia & Boharya \\
\hline 6 & & & Cyprinus carpio & Cyprinus \\
\hline 7 & & & Puntitus dorsalis & Podshi \\
\hline 8 & & & Puntitus chola & Tepri \\
\hline 9 & & & Puntitus ticto & Pepdi \\
\hline 10 & & & Tor khudree & Temri \\
\hline 11 & & & Osteobrama catio & Kharpati \\
\hline 12 & & & Hypothalmichthys molitrix & Chandera \\
\hline 13 & & & Salmostoma boopis & Chal/ Udan \\
\hline 14 & & & Lepidocephalus thermalis & Girgos \\
\hline 15 & & & Ambrichthys sandkhol & Sandkoli \\
\hline 16 & & & Tilapia mossambica & Mutri \\
\hline 17 & Perciformes & & Oreochromis mossambica & Talapia \\
\hline 18 & & & Glossogobinus giuris & Kombada \\
\hline 19 & & & & Dhangarya \\
\hline
\end{tabular}




\begin{tabular}{|l|l|l|l|l|}
\hline 20 & Synbranchiformes & Channidae & Channa marulis & Dokh \\
\hline 21 & & & Chanda nama & Chandva \\
\hline 22 & & Mastocembelidae & Macrognathus pancalus & Bam \\
\hline 23 & Siluriformes & Siluridae & Ompak bimaculatus & Patola \\
\hline 24 & & & Mystus cavasius & Katirna \\
\hline 25 & & & Sperata seenghala & Singhata \\
\hline 26 & Atheriniformes & Belonidae & Xenentodon cancila & Chatarya \\
\hline 27 & Osteoglossiformes & Notopteridae & Notopterus notopterus & Bhangad \\
\hline 28 & Anguilliformes & Anguillidae & Anguilla bengalensis bengalensis & Wire \\
\hline
\end{tabular}

Total 44 fishermen's were interviewed and it was reported that the socio-economic condition of fishermen using the survey indicators like age distribution, marital status, educational status, family type and family size, status accommodation, basic amenities status, working status of their spouse for supplement and family income status. Same work has been carried out by Oluwasola Oluwemimo et. al, (2013) were focus on socio-economic status including nutrition, poverty, employment, poor extension services etc. of fishermen living in Nigeria. According to Mridula Rani Das et. al, (2015) the livelihood status of fishermen's community in Batiaghata upazila of Khulna district, Bangladesh from

Table /Figure No. - 1 - Age distribution

\begin{tabular}{|c|c|c|}
\hline $\begin{array}{c}\text { Sr. } \\
\text { No. }\end{array}$ & $\begin{array}{c}\text { Age group of } \\
\text { Fishermen (in yrs) }\end{array}$ & $\begin{array}{c}\text { No. of } \\
\text { Fishermen }\end{array}$ \\
\hline 1 & $0-15$ & 03 \\
\hline 2 & $16-30$ & 27 \\
\hline 3 & $31-45$ & 07 \\
\hline 4 & $46-60$ & 05 \\
\hline 5 & $61-75$ & 02 \\
\hline
\end{tabular}

Table/Figure No. 2 - Educational Status

\begin{tabular}{|c|c|c|}
\hline $\begin{array}{c}\text { Sr. } \\
\text { No. }\end{array}$ & $\begin{array}{c}\text { Educational } \\
\text { Qualification of } \\
\text { Fishermen }\end{array}$ & $\begin{array}{c}\text { No. of } \\
\text { Fishermen }\end{array}$ \\
\hline 1 & Illiterate & 20 \\
\hline 2 & Upto SSC & 16 \\
\hline 3 & HSC & 06 \\
\hline 4 & Graduate & 02 \\
\hline
\end{tabular}

Feb. 2013 to Dec. 2013. The result of study revealed some interesting facts and showed that most of the involved fishermen are in 13-16 years age group (45\%) Whereas majority of them were Hindus (62\%). About $75 \%$ of fishing community was illiterate and $24 \%$ was literate. Salim Reza et.al, (2015) were conducted to investigate the socioeconomic and livelihood status of 25 fishermen randomly selected around the Atrai and Kankra rivers at Chirirbandar Upazila, Dinajpur from Ocbober 2013 to January 2014.

A detailed analysis of socio-economical status of fishermen depends on Uma River of Dist. Washim were discussed in following tables.
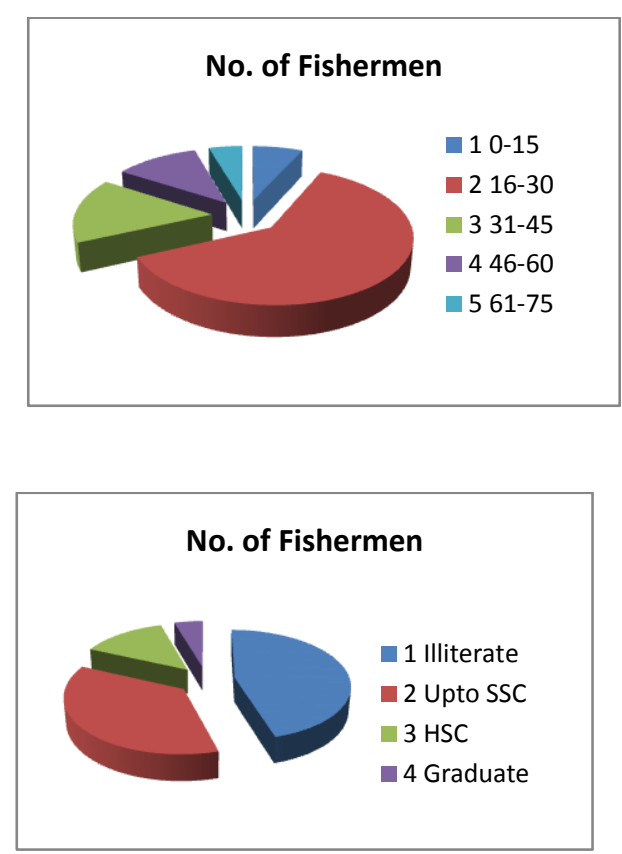
Table/Figure No. 3 - Marital Status

\begin{tabular}{|c|c|c|}
\hline $\begin{array}{c}\text { Sr. } \\
\text { No. }\end{array}$ & $\begin{array}{c}\text { Marital Status of } \\
\text { Fishermen }\end{array}$ & $\begin{array}{c}\text { No. of } \\
\text { Fishermen }\end{array}$ \\
\hline 1 & Unmarried & 06 \\
\hline 2 & Married & 38 \\
\hline
\end{tabular}

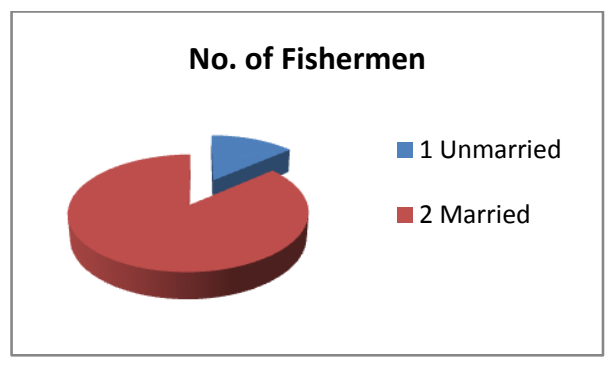

Table/Figure No. 4 - Family Type

\begin{tabular}{|c|c|c|}
\hline $\begin{array}{c}\text { Sr. } \\
\text { No. }\end{array}$ & $\begin{array}{c}\text { Fishermen Family type } \\
\text { and Size }\end{array}$ & $\begin{array}{c}\text { No. of } \\
\text { Members }\end{array}$ \\
\hline 1 & Smallest (1-3) & 10 \\
\hline 2 & Small (4-6) & 24 \\
\hline 3 & Medium (7-9) & 06 \\
\hline 4 & Large (10- and above) & 04 \\
\hline
\end{tabular}

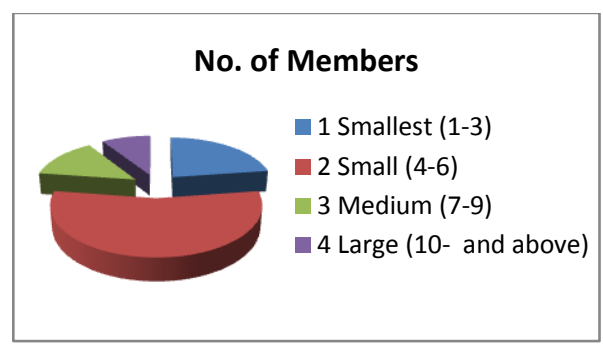

Table/Figure No. 5 - Fishermen Income/year

\begin{tabular}{|c|c|c|}
\hline $\begin{array}{c}\text { Sr. } \\
\text { No. }\end{array}$ & $\begin{array}{c}\text { Fishermen yearly } \\
\text { income (Rs.) }\end{array}$ & $\begin{array}{c}\text { Percentage of } \\
\text { fishermen }\end{array}$ \\
\hline 1 & $15000-25000$ & $73 \%$ \\
\hline 2 & $25001-35000$ & $15 \%$ \\
\hline 3 & $35001-50000$ & $08 \%$ \\
\hline 4 & 50001 and Above & $04 \%$ \\
\hline
\end{tabular}

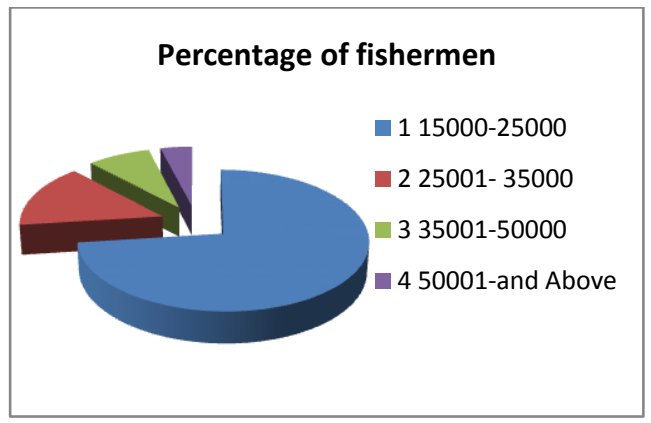

Table/Figure No. 6-Working Status of Spouse (Wife) for supplement family income

\begin{tabular}{|c|c|c|}
\hline $\begin{array}{c}\text { Sr. } \\
\text { No. }\end{array}$ & $\begin{array}{c}\text { Working status of } \\
\text { spouse (wife) }\end{array}$ & $\begin{array}{c}\text { Percentage of } \\
\text { Income }\end{array}$ \\
\hline 1 & Working & $20 \%$ \\
\hline 2 & Non-working & $80 \%$ \\
\hline
\end{tabular}

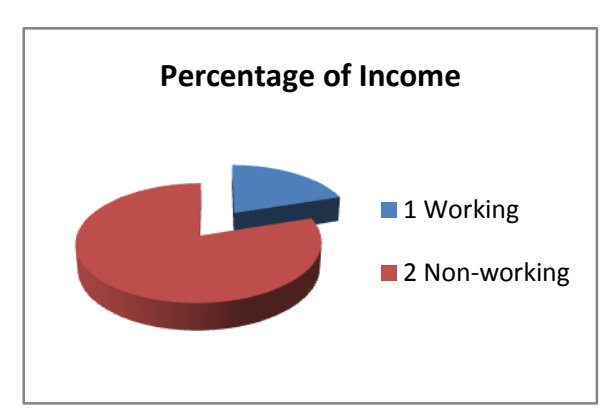


Table / Figure No. 7-Accommodation status of Fishermen

\begin{tabular}{|c|c|c|}
\hline $\begin{array}{c}\text { Sr. } \\
\text { No. }\end{array}$ & $\begin{array}{c}\text { Status of } \\
\text { Accommodation }\end{array}$ & Percentage \\
\hline 1 & Slum colony & $65 \%$ \\
\hline 2 & Own room in colony & $08 \%$ \\
\hline 3 & Chawls & $02 \%$ \\
\hline 4 & In rented room & $25 \%$ \\
\hline
\end{tabular}

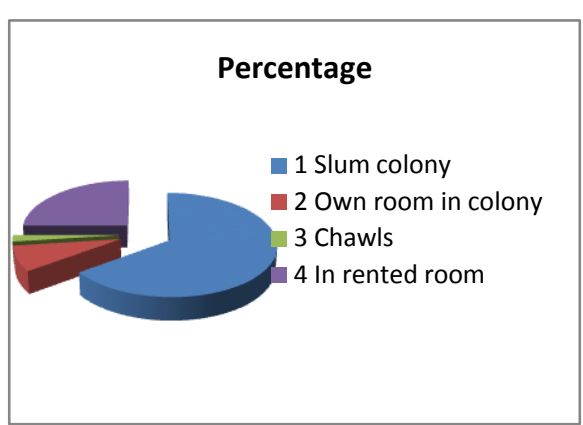

Table/Figure No. 8 (a) - Basic Amenities Status of Fishermen -Electric supply

\begin{tabular}{|c|c|c|}
\hline $\begin{array}{c}\text { Sr. } \\
\text { No. }\end{array}$ & Electric Supply & Percentage \\
\hline 1 & Permanent & $38 \%$ \\
\hline 2 & Temporary & $62 \%$ \\
\hline
\end{tabular}

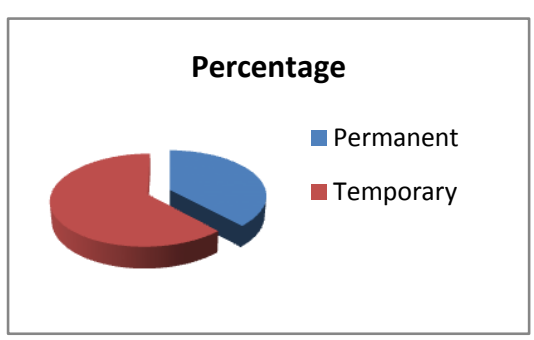

Table/Figure No. 8 (b)-Basic Amenities Status of Fishermen -Fuel facilities for Cooking

\begin{tabular}{|c|c|c|}
\hline $\begin{array}{c}\text { Sr. } \\
\text { No. }\end{array}$ & $\begin{array}{c}\text { Fuel facilities for } \\
\text { Cooking }\end{array}$ & Percentage \\
\hline 1 & Wood - Cowdung & $50 \%$ \\
\hline 2 & Kerosene & $20 \%$ \\
\hline 3 & LPG Connection & $30 \%$ \\
\hline
\end{tabular}

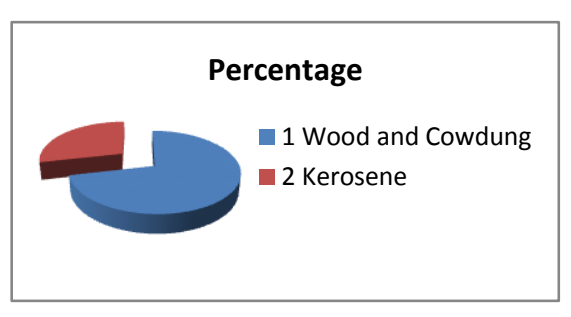

Table/Figure No. 8 (c) - Basic Amenities Status of Fishermen- Sources of drinking water

\begin{tabular}{|c|c|c|}
\hline $\begin{array}{c}\text { Sr. } \\
\text { No. }\end{array}$ & $\begin{array}{c}\text { Fuel facilities for } \\
\text { Cooking }\end{array}$ & Percentage \\
\hline 1 & Tap Water & $32 \%$ \\
\hline 2 & Tube Well & $55 \%$ \\
\hline 3 & River Water & $08 \%$ \\
\hline 4 & Pond Water & $05 \%$ \\
\hline
\end{tabular}

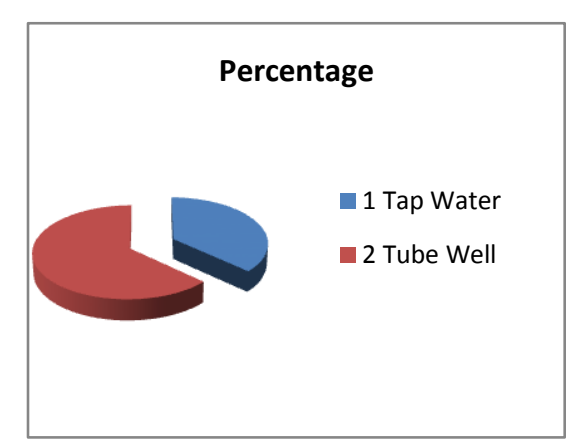


Table / Figure No. 8 (d) - Basic Amenities Status of Fishermen Sanitation practice used by fishermen family (Latrine)

\begin{tabular}{|c|c|c|}
\hline $\begin{array}{l}\text { Sr. } \\
\text { No. }\end{array}$ & $\begin{array}{c}\text { Sanitation practices used by } \\
\text { fishermen family (Latrine) }\end{array}$ & Percentage \\
\hline 1 & Kaccha & $20 \%$ \\
\hline 2 & Semipakka & $25 \%$ \\
\hline 3 & Pakka & $05 \%$ \\
\hline 4 & No Sanitary facility & $50 \%$ \\
\hline
\end{tabular}

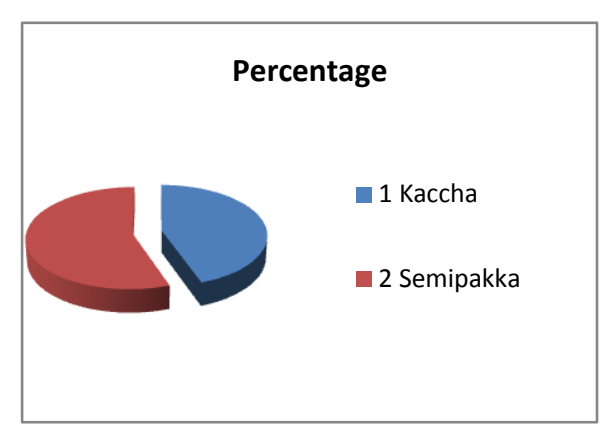

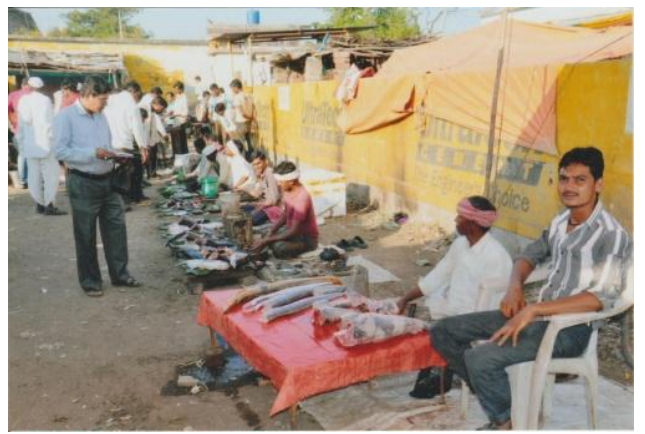

Photograph- III Personal Interview of fishermen in fish market of Kamargaon.

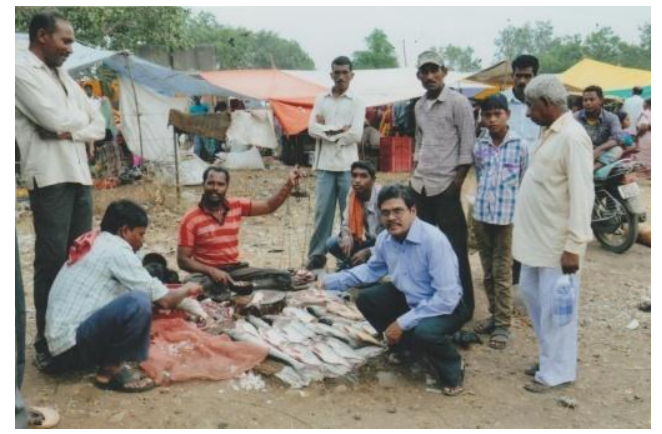

Photograph- V - Group Discussion

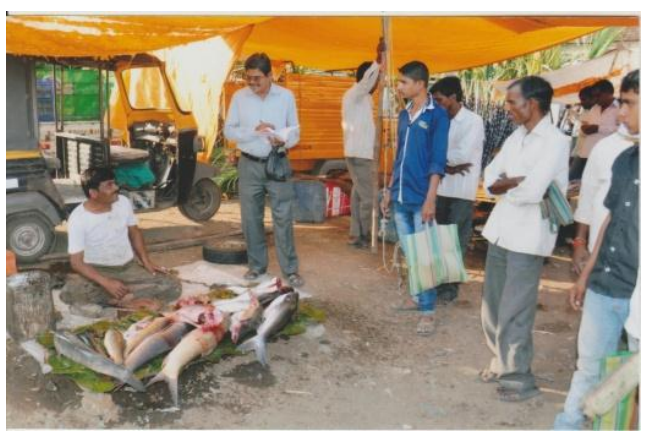

Photograph- IV - Group discussion

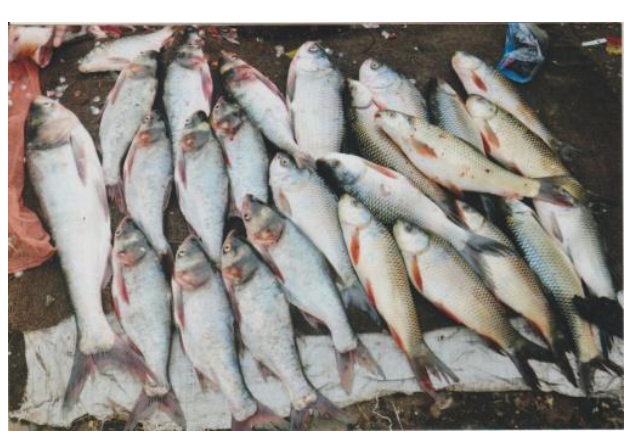

Photograph- VI - Young fishes sold in market before their maturity 


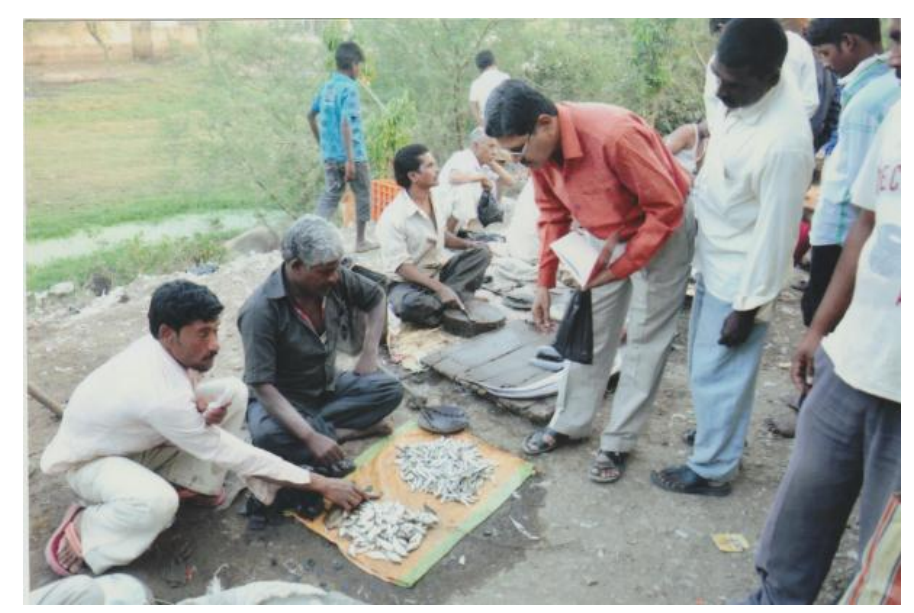

Photograph- VII - Semi-fingerling and fingerlings are sold in market.

Result of table no. 1 shows, the order cypriniformes was dominant with 16 fish species followed by order preciformes, synbranchiformes and siluriformes 3 whereas atheriniformes, osteoglossiformes and anguilliformes with one fish species. During present investigation the order of dominance is as follows. Cypriniformes > Perciformes - Synbranchiformes Siluriformes > Atheriniformes Osteoglossiformes - Anguilliformes.

The family cyprinidae was represented by 16 species, Catla catla, Labeo rohita, Cyprinus carpio, Puntitus ticto and Salmostoma boopis were found most abundant. The family siluridae was represented by 3 species Ompak bimaculatus, Mystus carasius and Sperata seenghala in which Ompak bimaculatus was found most abundant. The family cichlidae was represented by 2 fish species Tilapia mossambica and Oreochromis mossambica in which Tilapia mossambica was found most abundant. Also the family Channidae was represented by 2 fish species Channa marulis and Chanda nama in which Channa marulis was found most abundant. The family Belonidae was represented by one fish species Xenentodon cancila. The family Notopterus notopterus and the family Anguillidae was represented by Anguilla bengalensis bengalensis. According to $\mathrm{J}$. Chandra Sekhara Rao et. al, (2013) the result of the present study revealed that Uma river basin being a freshwater resource supports a rich and diversified fish fauna. However, itchthyofaunal diversity of this river is in declining mode due to several anthropogenic threats. In order to conserve these valuable resources, a holistic approach, integrating the concept of sustainable development and conservation measures should be adopted.

The result of table no. 2 indicates that the investigation showed majority of the fishing professional belongs to 16-30 age groups while the 61 and above aged class has been lowest involvement. Table no. 3 indicates that joint families are continuously decreasing in the fishermen society. Table no. 4 indicates most of the fishermen are married. Table no. 5 indicates most of the fishermen family is small whereas the joint families are in declining mode. Table no. 5 indicates fishermen belong to low income category. Table no. 7 indicates that very few wife's of fishermen gives financial support to their family. Table no. 8 indicates that maximum fishermen are living in slum area whereas very few families of fishermen are live in their own house. Table no. 9-12 indicates that the condition of basic amenities like electricity, fuel sources of drinking water and sanitation were not satisfactory. Table no. 13 indicates that fishermen's depends on Uma River Basin Dist. Washim were not aware of life insurance policies. Only few of them have taken insurance policies to cover the risk of their life. 


\section{Conclusion:}

The socio-economic condition of the fishermen in adjacent area of Uma River was not satisfactory. The fishermen were deprived of many facilities. The education level of the fishermen was so poor due to lack of awareness in literacy. The present research indicates that there is ample scope to increase the income of fishermen for that purpose it is necessary to adapt improved fishing and fish culture practices on scientific basis. The social and educational status of the fishermen could also be include by educating them in various aspects like, awareness about good health and hygiene. The NGOs should provide lone facilities for solving their family problems.

\section{References:}

Jadhav B.V., Kharat S.S., Raut R.N., Paingankar M., and Dahanukar N., (2011): Freshwater fish fauna of Koyna River, Northern Western Ghats, India. Journal of Threatened Taxa January 2011., 3 (1): pp 1449-1455

Jayabhaye U.M., and Lahane L.D. (2013): Studies on Ichthyofaunal diversity of Pimpaldari tank, Hingoli, Maharashtra, India. International Indexed and Referred Research Journal, ISSN 0975-3486, (Print)EISSN-2320-5482, April-May (Combined), 2013 VOL-4 ISSUE 43-44 pp.54-55

Jayaram K.C. and Sanyal A. (2003): A taxonomic revision of he fishes of the genus Mystus scopoli (Family: Begridae) Records of the Zoological survey of India occasional paper no. 207 ZSI Culcatta pp. 141

J. Chandra Sekhara Rao G. Simhachalam \& CH. Sebastian Raju (2013): A study on Ichthyofaunal diversity, conservation status and Anthropogenic stress of River Champavati, Vizianagaram District (AP) India. ASIAN J. EXP. BIOL. SCI. VOL 4(3), P. 418-425

Kar, Kumar D. A., Bohra C., \& Singh L. K. (EDS) (2003): Fishes of Barak drainage, Mizoram and Tripura. In: Environment, Pollution and Management. Publishing corporation, New Delhi, 604: pp. 203-211

Kharat S.S., Paingankar M., and Dahanukar N. (2012): Freshwater fish of Krishna River at Wai, northern Western Ghats, India. Journal of Threatened Taxa June 2012., 4 (6): pp 2644-2652

Mridala R. D., Sunuram R., Uttam K., Salma B., and Satya R. T. (2015): Livelihood Assessment of the Fishermen Community in the South West Region of Bangladesh., Journal of Experimental Biology and Agricultural Sciences 2015, Vol 3 (4): pp. 353- 361
Nagma and Khan Afzal M. (2013): Studies on freshwater fauna of district Bijnor in Western Utter Pradesh, India., Int. J. LifeSc. Bt \& Pharm Res. Vol. 2 (3): pp 410-417

Oluwasola Oluwemimo and Ajayi Damilola (2013): Socio-economic and policy issues determining sustainable fish farming in Nigeria., International Journal of Livestock Production Vol 4 (1): pp. 1-8

Salim Reza, Md. Sazzad Hossain, Ujjwal Hossainm Md. Abu Zafar. (2015): Socioeconomic and livelihood status of fishermen around the Atrai and Kankra Rivers of Chirirbandar Upazila under Dinajpur District., International Journal of Fisheries and Aquatic Studies 2015 Vol 2 (6): pp 402408

Shinde S. E. (2009): Fish Biodiversity of Pravara River at Pravara Sangam District Ahmednagar, (M.S.) India., World Journal of Zoology 20094 (3): pp. 176-179

Talwar P.K and Jhingran A. (1991): Inland fishes of India and adjascent countries, Vol. 1 and 2, Oxford and IBH Publisher, New Delhi. pp. 1-158

Thirumala S., Kiran B. R. and Kantaraj G. S. (2011): Fish Diversity in relation to Physico-chemical characteristics of Bhadra reservoir of Karnataka, India., Advances in Applied Science Research, 2011, Vol 2 (5): pp. 34-47 